\title{
Plantation forestry diseases in Zambia: Contributing factors and management options
}

\author{
Donald Chungu ${ }^{1,2 *}$, Ambayeba Muimba-KAnKolongo ${ }^{2}$, Michael J. WingFiELD ${ }^{1}$, \\ Jolanda RoUX ${ }^{1}$ \\ ${ }^{1}$ Department of Microbiology and Plant Pathology, Forestry and Agricultural Biotechnology Institute (FABI), \\ University of Pretoria, Pretoria 0002, South Africa \\ ${ }^{2}$ School of Natural Resources, Department of Forest Resources Management, Copperbelt University, Kitwe, Zambia
}

(Received 11 September 2009; accepted 5 January 2010)

Keywords:

fungal pathogens /

Africa /

fire ecology /

silviculture /

selection

\begin{abstract}
- Plantation forestry in Zambia is based mainly on non-native Eucalyptus and Pinus species and constitutes an important component of the country's economy. The productivity of these plantations is, however, threatened by several factors, including fungal pathogens that reduce timber quality and cause tree mortality.

- In this paper we present a review of diseases affecting plantation forestry and highlight factors that may favour their development and severity in the country.

- Plantation health management in the country is seriously hampered by a general lack of information on pests and diseases affecting these plantations. In this regard, most research has been done more than 30 years ago, and very few pathogens have been identified to species level using modern identification techniques.

- Recent surveys identified several previously unknown diseases of Eucalyptus spp. in the country, emphasizing the importance of renewed research on this topic. The impact of diseases associated with these pathogens has been exacerbated by poor plantation management, insufficient financial resources and lack of human capacity to deal with them.

- Successful plantation management in Zambia will require increased and improved training of foresters regarding tree health issues, more effective quarantine, silvicultural practices, and importantly, the establishment of sound breeding and selection programmes. These will require considerable commitment from Government, commercial companies and research and educational organizations in the country.
\end{abstract}

\section{INTRODUCTION}

Increasing demand for wood and wood products has exerted pressure on natural forest resources throughout the world, including in Zambia. These resources are currently under threat due to many factors, the most important being clearing of forest land for agricultural production. At a time when the world average annual forest loss stands at $0.2 \%$ and that of Africa at about $0.8 \%$, Malawi and Zambia experience considerable losses amounting to about $2.4 \%$ per annum (FAO, 2007). The need to accommodate the increasing demand for fibre and wood products in Africa has led to an increase in establishment of plantations of non-native tree species, particularly $\mathrm{Eu}$ calyptus and Pinus (Evans, 1992). These plantations have an important economic and social bearing for several countries in Africa providing a source of employment, wealth creation, the production of export capital as well as fuel and construction timber.

*Corresponding author: donald.chungu@ fabi.up.ac.za
Despite the importance of forestry plantations, they face a number of threats, amongst which pests and diseases are the most damaging. In this regard, large areas of land, particularly those dominated by a few tree species with a limited genetic base, are at risk due to possibly serious disease and pest outbreaks (Roberds et al., 1990; Wingfield et al., 2008). International examples include losses caused by Dothistroma needle blight of Pinus spp. in Chile, New Zealand and Kenya (Gibson, 1975) and the recent outbreak of Phytophthora pinifolia A. Durán, Gryzenh and Wingf. in Chile (Durán et al., 2008).

In Africa, there are numerous examples of non-native forestry plantations that have been substantially damaged by the accidental introduction of non-native pests and pathogens. Dothistroma needle blight of Pinus spp., caused by Dothistroma septosporum (Dorog.) M. Morelet (Barnes et al., 2004), for example, led to the termination of P. radiata D. Don planting in many African countries, particularly those in East Africa (Gibson et al., 1964). Similarly, the susceptibility of Eucalyptus globulus Labill to the snout beetle, Gonipterus scuttelatus Gyllenhal, and Mycosphaerella leaf disease led to 
Table I. Average incidence, severity and number of leaf spots, and related crown damage index on Eucalyptus grandis and E. cloeziana at Copperbelt Forestry Company Kalibu and Kafubu plantations, Copperbelt Province, Zambia ${ }^{a}$.

\begin{tabular}{lcccccc}
\hline & & & & \multicolumn{2}{c}{ Average No. of spots/leaf on } \\
\cline { 5 - 7 } Plot No. & Incidence $(\%)^{b}$ & Severity $^{c}$ & $\begin{array}{c}\text { Crown damage } \\
\text { index }^{d}\end{array}$ & Top & Middle & Bottom \\
\hline Kalibu (E. grandis) & & & & & & \\
1 & 30.0 & 11.2 & 30.8 & 6.3 & 10.5 & 15.3 \\
2 & 100.0 & 4.0 & 4.4 & 0.7 & 4.7 & 20.2 \\
3 & 27.0 & 19.0 & 19.3 & 19.5 & 30.3 & 23.4 \\
4 & 79.0 & 5.0 & 6.2 & 10.3 & 26.0 & 19.3 \\
5 & 40.0 & 15.3 & 33.4 & 37.0 & 51.3 & 49.0 \\
Mean & 55.2 & 10.9 & 18.8 & 14.8 & 24.6 & 25.4 \\
Kafubu (E. cloeziana) & & & & & \\
1 & 49.3 & 15.3 & 46.3 & 41.3 & 34.8 & 36.5 \\
2 & 100.0 & 3.5 & 3.0 & 1.3 & 9.0 & 13.3 \\
3 & 100.0 & 22.7 & 62.0 & 53.5 & 51.8 & 67.5 \\
4 & 94.7 & 16.0 & 29.1 & 30.3 & 35.7 & 40.3 \\
5 & 41.0 & 35.3 & 115.9 & 76.8 & 90.2 & 131.7 \\
Mean & 77.0 & 18.7 & 51.3 & 40.6 & 44.3 & 57.9 \\
\hline
\end{tabular}

${ }^{a}$ Copperbelt Forestry Company, Kitwe, Zambia, 2009 (unpublished report).

${ }^{b}$ Damage incidence of leaf spots calculated as percentage tree crown damaged by the disease.

${ }^{c}$ Severity of leaf spots on the tree crown determined on a 1 to 6 scoring scale where $1=$ a tree with leaves damaged at $3 \%$, class $2=6 \%$, class $3=12 \%$, class $4=25 \%$, class $5=50 \%$ and class $6=75 \%$ leaf spot infection.

${ }^{d}$ Crown Damage Index being the sum of products of damage incidence and severity leaf spots.

the planting of this species being terminated in South Africa (Purnell and Lundquist, 1987).

An outbreak of diseases in one African country can threaten the health status of plantation forestry in others. Increased trade amongst countries and free movement of people and products on the continent have increased the risks of diseases spreading across borders. Thus, during the past few years, many countries have adopted regulations aimed at curtailing pest risks associated with the free movement of people and goods.

In order to contain pest and pathogen problems, there is a need for knowledge regarding the prevailing sanitary problems and to understand their distribution and patterns of spread. An important first step towards effective disease control is to review the status of plantation forest health. Thus, the aim of this review is to provide an overview of plantation forestry diseases in Zambia. We consider some of the factors influencing disease development and strategies to minimize disease outbreaks in the country.

\section{LEAF DISEASES OF EUCALYPTS}

\subsection{Corky leaf spot}

Corky leaf spot caused by Aulographina eucalypti (Cooke and Massee) Arx and E. Müll. has been reported from E. grandis W. Hill and E. cloeziana F. Muell in Chati and Kitwe in the Copperbelt region of Zambia (Muimba-Kankolongo et al., 2009). This is not surprising because A. eucalypti is a common pathogen of Eucalyptus spp. in Australia (Carnegie et al., 2007), the origin of plantation propagation material. The disease was more prevalent at the beginning of the warm season, mainly in five-year-old stands (Tabs. I, II), with E. grandis being affected more severely than E. cloeziana (MuimbaKankolongo et al., 2009). This was consistent with previous findings by Wall and Keane (1984) that infection by A. eucalypti mainly occurs during periods when temperatures range between $15^{\circ} \mathrm{C}$ and $20{ }^{\circ} \mathrm{C}$, which are optimal for its sporulation.

\subsection{Mycosphaerella leaf disease}

Mycosphaerella leaf disease (MLD), caused by fungal species now classified in Teratosphaeria, is a widespread and economically important disease of Eucalyptus spp. worldwide (Crous et al., 2007). Three species of Teratosphaeria have been reported from Zambia. These are T. pseudafricana Crous and T. Coutinho, T. nubilosa (Cooke) Hansf. and its anamorph Passalora zambiae Crous and T. Coutinho (Crous et al., 2006). T. pseudafricana and $P$. zambiae are known only from Zambia where they infect E. globulus (Crous et al., 2006). However, information regarding their impact or distribution in the country is not available in the literature. T. nubilosa was reported to cause severe leaf spots on E. globulus (Crous et al., 2006), but since E. globulus is not planted widely in the country, the disease is not currently considered important.

Surveys in forestry plantations in the Copperbelt Province by Muimba-Kankolongo et al. (2009) recorded several leaf spot diseases on E. grandis and E. cloeziana. However, the authors did not identify the causal agents to species level and their identification protocol was based solely on field symptoms and spore morphology in cultures. Amongst the diseases 
Table II. Incidence of leaf blight and stem cankers in Eucalyptus grandis and E. cloeziana at Copperbelt Forestry Company plantations in Kalibu and Kafubu, Copperbelt Province of Zambia ${ }^{a}$.

\begin{tabular}{|c|c|c|c|c|}
\hline \multirow[b]{2}{*}{ Plot number } & \multicolumn{2}{|c|}{ Incidence of leaf blight $(\%)^{b}$} & \multicolumn{2}{|c|}{ Incidence of stem cankers $(\%)$} \\
\hline & Kalibu & Kafubu & Kalibu & Kafubu \\
\hline Plot 1 & 1.0 & $\ldots^{d}$ & 24.4 & 1.1 \\
\hline Plot 2 & 10.0 & $\ldots$ & 6.9 & 18.8 \\
\hline Plot 3 & 2.0 & $\ldots$ & 37.0 & 26.7 \\
\hline Plot 4 & 4.8 & $\ldots$ & 9.7 & 11.6 \\
\hline Plot 5 & 2.8 & $\ldots$ & 14.7 & 23.7 \\
\hline Plot 6 & 2.0 & $\ldots$ & 11.9 & 14.7 \\
\hline Plot 7 & $\ldots$ & $\ldots$ & 3.1 & 12.0 \\
\hline Plot 8 & $\ldots$ & $\ldots$ & 5.2 & 13.7 \\
\hline Average & 7.5 & $\ldots$ & 14.1 & 15.3 \\
\hline Statistical & & & $* * *$ & $* * *$ \\
\hline difference $^{e}$ & $\cdots$ & & $* * *$ & $* * *$ \\
\hline Prob $>F$-test & $\ldots$ & $\ldots$ & \multicolumn{2}{|c|}{0.4755 (ns) } \\
\hline
\end{tabular}

${ }^{a}$ (C) 2009, NISC, Muimba-Kankolongo et al.

${ }^{b}$ Incidence expressed as percentage of trees with leaf blight symptoms over the total number of trees in the plot at Kalibu (E. grandis) and Kafubu (E. cloeziana).

${ }^{c}$ Incidence expressed as percentage of trees with stem cankers over the total number of trees in two quadrants per plot at Kalibu (E. grandis) and Kafubu (E. cloeziana).

${ }^{d}$ Leaf blight symptoms not observed in E. cloeziana plantations at Kafubu.

${ }^{e}$ ns stands for mean values not significantly different from zero at $P \leq 0.05$.

reported, MLD was found on several plants of both $E$. grandis and $E$. cloeziana, but at a lower incidence compared to other diseases. Because E. globulus, E. nitens and other species highly susceptible to MLD are not grown commercially in the country, severe outbreaks of the disease, such as those in South Africa (Hunter et al., 2009) are unlikely in the country.

\subsection{Pseudocercospora leaf disease}

Pseudocercospora spp. are known as leaf pathogens of $E u$ calyptus spp. in Southern Africa (Wingfield, 1987). In Zambia, a disease caused by a fungus identified as Pseudocercospora sp. was recently reported from $E$. grandis and $E$. cloeziana in young plantations (Muimba-Kankolongo et al., 2009). The exact identity of the pathogen, the severity of damage and the distribution of the disease in the country is, however, not known.

\subsection{Kirramyces leaf disease}

Kirramyces epicoccoides (Cooke and Massee) J. Walker, B. Sutton and Pascoe has been the main causal agent of Kirramyces leaf disease in Africa (Crous et al., 2007). The disease predominantly occurs on various Eucalyptus spp. including E. globulus and E. camaldulensis Dehnh in the SADC region (Wingfield, 1987). Kirramyces leaf disease has been reported from E. tereticornis Sm trees in Zambia and in a five-year-old Eucalyptus plantation in Mwekera (Shakacite, 1991). It was reported to be more severe in the rainy than the dry season (Shakacite, 1991). In the recent past, the disease has also been observed on E. grandis and E. cloeziana in Kitwe, Copperbelt Province (Muimba-Kankolongo et al., 2009).

\subsection{Cylindrocladium leaf disease}

Although Cylindrocladium spp. are amongst the most important Eucalyptus leaf pathogens in many parts of the world, reports of these pathogens in Africa have been sporadic. In South Africa, Cylindrocladium pauciramosum C.L. Schoch and Crous is a serious pathogen of Eucalyptus spp. in forestry nurseries (Crous et al., 1993). Similarly, C. candelabrum C.L. Schoch and Crous has been associated with severe leaf blight of Eucalyptus spp. in the Republic of Congo (Roux et al., 2000). In Zambia, Cylindrocladium leaf disease was recently reported in young $E$. grandis plantations on the Copperbelt Province (Muimba-Kankolongo et al., 2009). Although this disease has not been common in older plantations, it is a potential threat to plantation establishment in the country.

\section{STEM DISEASES OF EUCALYPTS}

\subsection{Botryosphaeria canker}

Stem cankers and die-back of eucalypts caused by species in the Botryosphaeriaceae are the most common diseases of eucalypts. In Africa, species such as Neofusicoccum ribis (Pennycook and Samuels) Crous, Slippers and A.J.L. Phillips, N. parvum (Pennycook and Samuels) Crous, Slippers and A.J.L. Phillips and N. eucalyptorum (Crous, H. Sm. Ter and M.J. Wingf.) Crous, Slippers and A.J.L. Phillips are most prevalent (Slippers and Wingfield, 2007), but often associated with trees that have been predisposed by other factors. Symptoms characteristic of Botryosphaeria canker (Fig. 1) have been observed on E. grandis and E. cloeziana in Zambia (Muimba-Kankolongo et al., 2009). Symptoms of the disease included die-back of the growing tips, coppice failure and 


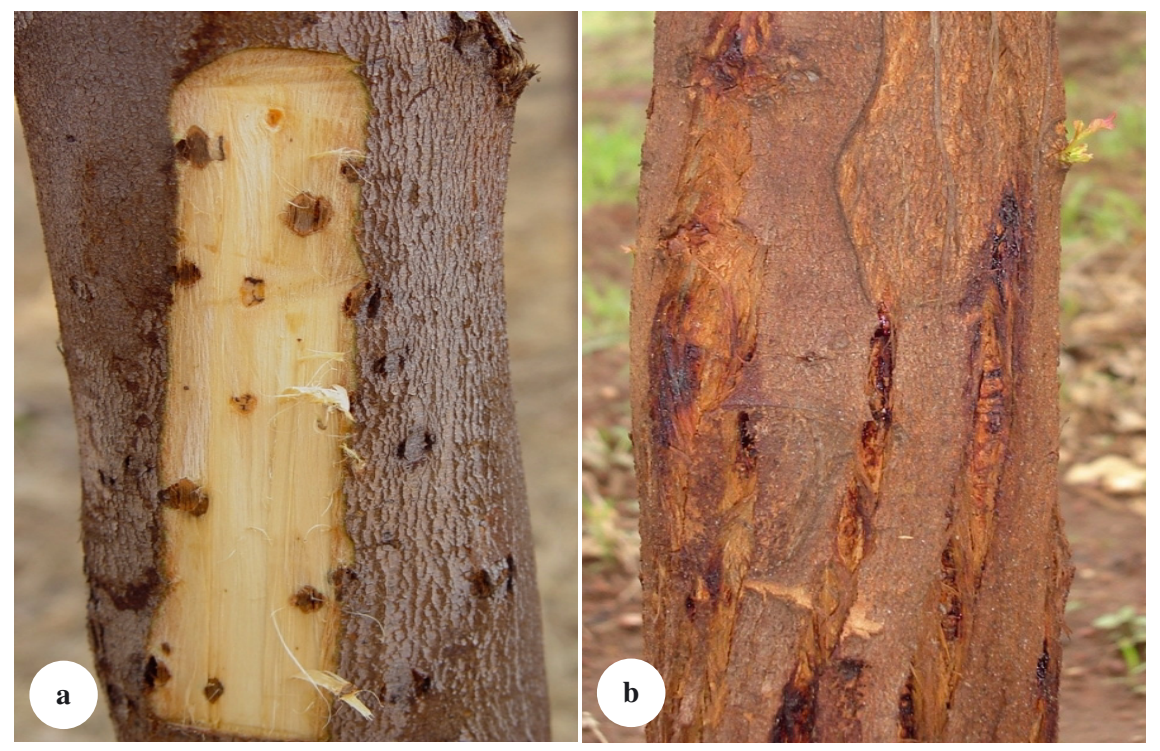

Figure 1. Stem cankers on Eucalyptus grandis plantation at Kalibu, Kitwe District in Copperbelt Province of Zambia. (a) Internal bark damage caused by Kirramyces sp. and (b) cankers induced by Botryosphaeriaceae. Copyright 2009 NISC, Muimba-Kankolongo et al. (A color version of this figure is available at www.afs-journal.org.)

cankers on stems, often characterised by kino exudation. The disease was more prevalent in six-year old E. grandis plantations in Kitwe than in E. cloeziana plantations in Chati in the Copperbelt Province (Tab. II). Identification to the species level of the Botryosphaeriaceae associated with the disease has yet to be undertaken.

\subsection{Chrysoporthe canker disease}

Chrysoporthe species cause the disease commonly known as Cryphonectria canker on Eucalyptus spp. (Gryzenhout et al., 2009). In Africa, Chrysoporthe spp. have been reported as the causal agents of stem cankers on eucalypts in Cameroon, Democratic Republic of Congo, Ghana, Malawi, Mozambique, Republic of Congo and Zambia (Chungu et al., 2010; Nakabonge et al., 2006; Roux and Apetorgbor, 2009; Roux et al., 2000). In Zambia, the pathogens associated with Cryphonectria canker on E. grandis were identified as $C h r$. austroafricana Gryzenh. and M.J. Wingf. (Nakabonge et al., 2006) and Chr. zambiensis Chungu, Gryzenhout and Jol. Roux (Chungu et al., 2010). The disease could seriously affect forestry plantation development in the country (MuimbaKankolongo et al., 2009). Substantial success has, however, been achieved in the management of Cryphonectria canker through breeding for resistance. In South Africa and South America, clones tolerant to infection have been identified from natural screening and artificial inoculation trials (Van Heerden and Wingfield, 2002; Wingfield et al., 1991) and similar strategies can be used in Zambia.

\subsection{Coniothyrium canker disease}

Coniothyrium canker, caused by species of Teratosphaeria, is widespread in Eucalyptus plantations in several African countries including Zambia, Uganda, Ethiopia, Malawi, Mozambique, and South Africa (Roux et al., 2005; Wingfield et al., 1997). The disease was first reported from South Africa in 1997, resulting in substantial losses to the local forestry industry (Wingfield et al., 1997). Since then, it has emerged as one of the most damaging diseases of plantation-grown $\mathrm{Eu}$ calyptus spp. in the world. Two species of Teratosphaeria, T. zuluensis (M.-N. Cortinas, Crous and M.J. Wingf.) M.J. Wingf. and Crous and T. gauchensis (M.-N. Cortinas, Crous and M.J. Wingf.) M.J. Wingf. and Crous cause Coniothyrium canker in Africa (Cortinas et al., 2006). T. zuluensis is currently known only from South Africa and Malawi, while $T$. gauchensis occurs in Ethiopia and Uganda (Cortinas et al., 2006). The species causing this disease in Mozambique and Zambia has not been identified.

\section{DISEASES OF PINE}

\subsection{Dothistroma needle blight}

Red band needle blight disease of pines is caused by two distinct pathogens, namely $D$. septosporum and $D$. pini Hulbary, both anamorphs of Mycosphaerella pini sensu lato (Barnes et al., 2004). This disease is known to affect over 60 different pine species worldwide, of which $P$. radiata is the most susceptible (Ivory, 1994). Severe damage associated with the disease in many countries has led to the termination of pine plantations established using susceptible species. This is one of the most important diseases of Pinus spp. and it resulted in the termination of $P$. radiata planting in East Africa as well as huge economic losses in many countries (Gibson et al., 1964; Van der Pas, 1981). In Africa, the disease on 
$P$. radiata has been reported from several countries including Uganda, South Africa (Barnes et al., 2004), Kenya and Tanzania (Gibson et al., 1964; Van der Pas, 1981). The disease has also been recorded from $P$. kesiya Royle ex Gordon plantations in Zambia (Ivory, 1994), although no details regarding its distribution were provided. However, future outbreaks of red band needle blight disease are unlikely to occur in the country since $P$. radiata is not commercially grown.

\subsection{Armillaria root rot}

Armillaria root rot, caused by Armillaria spp., is widespread and causes death of numerous woody plants including plantation grown trees such as species of Acacia, Eucalyptus and Pinus. The disease has been reported in pine plantations in various countries in the Southern African Development Community (SADC) region (Roux et al., 2005; Wingfield et al., 2009). In Zambia, Mwenje and Ride (1996) reported Armillaria root rot on $P$. kesiya and $P$. oocarpa Schiede.

The causal agent of Armillaria root rot in Zambia was identified as A. mellea sensu lato (Mwenje and Ride, 1996) based only on macro and micro-morphological characteristics of the basidiocarps. However, identification of Armillaria spp. based on morphological characteristics is not practical because basidiocarps rarely occur in nature and when they do, they are ephemeral (Kile and Watling, 1981). Furthermore, recent DNA-sequence based identification of isolates of Armillaria from Pinus spp. in South Africa, Zimbabwe and several other African countries have shown that the fungus generally considered as A. mellea represents several different species (Coetzee et al., 2005). Although the causal agent of Armillaria root rot in Zambia remains to be determined, it is likely to include one or more of the four species that are known to occur in the region (Coetzee et al., 2005). There is no reliable information available regarding the geographic distribution or impact of the disease on non-native trees in the country.

\section{FACTORS AFFECTING FOREST PLANTATION HEALTH IN ZAMBIA}

\subsection{Planting material}

Plantation forestry in Zambia is based solely on non-native Eucalyptus and Pinus species, for which the seeds and planting material are primarily imported. A number of countries from which this material is imported have diseases that have not yet been reported in the country, presenting a considerable quarantine threat. For example, South Africa is one of Zambia's main sources of tree seed and diseases such as Pitch canker of Pinus spp. (Coutinho et al., 2007) and Quambalaria shoot blight of Eucalyptus (Roux et al., 2006), two serious plantation diseases are well established in that country.

Recently, planting material imported from other countries has not been bred and selected for local conditions in Zambia. It is consequently not ideally suited to this new environment.
This site-species mismatch adds stress to trees and exposes them to pests and pathogens to which they do not have natural resistance. Additionally, it makes them more prone to diseases caused by opportunistic pathogens, such as those in the Botryosphaeriaceae (Smith et al., 1996; Zwolinski et al., 1990).

\subsection{Poor silvicultural practices}

Poor planting techniques results in high levels of seedling mortality at the early stages of plantation establishment in Zambia. For example, seedlings are planted in shallow pits exposing their roots to heat and sun (Fig. 2a). This practice reduces growth and increases mortality. In addition, fertiliser application at the time of tree planting, which can greatly improve the vigour and survival of trees subsequent to establishment (CSIRO, 1996), is not practiced commercially in Zambia, due to high costs. This is unfortunate as fertilizer applications in forestry plantations has, for example, been reported to lead to a $38 \%$ higher MAI (mean annual increment) for $P$. radiata (CSIRO, 1996).

Failure to apply practices such as pruning, thinning, fertilizer applications and other silvicultural procedures correctly can enhance the susceptibility of trees to diseases. Evans (1992), observed that in order to increase tree vigour and subsequently improve the quality of sawn timber, thinning practices should be given considerable priority, especially in sawn timber rotations. Thinning in Zambian plantations, however, depends in most cases on market demand for timber, rather than on a plantation maintenance schedule. As long as the sale of thinnings cannot cover the costs of this operation, thinning will not be undertaken and this results in overstocking (Fig. 2d). This is likely to lead to soil nutrient deficiency because of increased competition, and thus increased pest and disease problems.

Sub-optimal planting and harvesting practises are of considerable concern in Zambia because these result in increased stress and tree mortality. The demand for sawn timber in the country has resulted in a considerable proliferation of smallscale sawmilling plants, and these have in turn led to accelerated and continuous harvesting of timber from plantations. Because sub-optimal timber harvesting and logging methods are practised, considerable damage is inflicted on standing trees. This provides entry sites for pathogens and insects and increases stress on trees (Sichinga, 2008).

\subsection{Fire}

Zambia has dry and hot summer months (AugustNovember) and damage due to fires in this period can be devastating. The Food and Agricultural Organization (FAO) (2007) estimated that in tropical regions, especially in savannah areas, fires destroy 0.5 to 1 billion ha of forests per year. In Zambia, losses of up to $0.3 \%$ of plantations occur annually due to fire (Chisanga and Banda, 2004). Humans are the main cause of fires, usually through hunting, charcoal and 



Figure 2. Factors affecting plantation forestry health in Zambia. (a) Poor planting technique. (b, c) Fire damage of Eucalyptus trees resulting in wood rot. (d) A poorly managed Pinus kesiya plantation with overstocking in the Southern Province of Zambia. (A color version of this figure is available at www.afs-journal.org.)

agricultural production activities. In addition to killing trees, Chidumayo (1989) observed that uncontrolled bushfires damage forest plantations and they predispose surviving trees to considerable stress and the onset of various diseases.

Fires cause cracks on tree stems through which decay causing fungi (Figs. 2b, 2c) and insects, including termites, gain ingress into tree tissues. Fires of high intensity also destroy soil organic matter and heat the soil resulting in hydrophobic or water repellent layers, which can considerably reduce moisture infiltration rates resulting in increased erosion (Chidumayo, 1989). At high temperatures, considerable nitrogen and other nutrient losses also occur, leading to nutrient deficiency (Chisanga and Banda, 2004). Both reduced moisture infiltration and nutrient deficiency induce stress, thereby increasing the vulnerability of trees to fungal and insect attack. Furthermore, fire has been shown to stimulate the germination of the root rot fungus, Rhizina undulata Fr., in Pinus plantations (Gibson, 1975). Spores of $R$. undulata, which are prevalent throughout pine-growing areas of southern Africa, require temperatures in excess of $37{ }^{\circ} \mathrm{C}$ for germination (Gibson, 1975). Following fire outbreaks, spores germinate and infect pine roots causing root rot and tree death. $R$. undulata has not been reported from Zambia but its accidental introduction could lead to serious sanitary problems in Pinus plantations because of recurrent bushfires.

\subsection{Environmental stress}

Environmental conditions play an important role in enabling pathogen infection and establishment in stressed trees. This subject has been reviewed for forest pathogens in Africa by previous authors (Slippers and Wingfield, 2007; Van Heerden and Wingfield, 2002; Wingfield and Knox-Davies, 1980; Zwolinski et al., 1990). Drought and high temperatures constitute important environmental factors that predispose plantation trees to diseases. For the past two decades, Zambia has experienced periodic droughts such as the prolonged drought that occurred during 1992-1993. Since then, 
most parts of the country, including the Copperbelt, where the majority of non-native tree plantations exist, have received erratic rainfall. Trees growing under stressful conditions are known to be more susceptible to infection by opportunistic pathogens such as those in the Botryosphaeriaceae (Slippers and Wingfield, 2007). However, the extent to which drought conditions will influence disease development in plantations is not known.

\subsection{Inadequate human capacity and research infrastructure}

A major component of successful plantation forestry is the implementation of sound tree-health management strategies that are supported by well trained personnel. Prior to 1980 , research on diseases of native and non-native trees was a core component of forestry research in Zambia. Currently, however, forestry research has a very limited pool of trained people to effectively carry out the required research and monitoring activities for the country. A crucial point is also the lack of tree breeders in the country. It is well established that longterm sustainability and success of disease control in plantation forestry relies on sound tree breeding and selection programmes. Tree breeders ensure that the best performing trees, tolerant to locally occurring pests and diseases, are grown on appropriate sites. The limited human capacity is further hampered by a lack of sustained funding and infrastructure to support research in tree breeding and plant diseases.

\section{CONCLUSIONS AND RECOMMENDATIONS}

Plantations of Pinus and Eucalyptus species in Zambia suffer from a number of disease problems. However, from this review, it is clear that numerous important diseases known from other countries, in Africa and globally, have not been observed in the country. Not unexpected, novel pathogens such as Chr. zambiensis and $P$. zambiae, not known from any other country, have also been described from Zambia. The impact of these diseases can result in substantial economic losses to the forestry industry if left unchecked. Effective disease control strategies are available and can be implemented successfully.

Three broad categories of plant disease control are known, namely prevention, eradication and management. Prevention relies on effective quarantine measures to minimize the risks of introduction of new pests and pathogens. Eradication relies on monitoring programmes so that outbreaks of diseases are discovered sufficiently early for effective interventions. These two approaches are marginally effective and tree disease management, including chemical and biological control, breeding and selection, is most commonly the only option available. All control strategies, however, rely on the availability of funds and trained staff to implement them. Unfortunately, the reality in most developing countries, including Zambia, is that the best options available for disease and pest management in plantations are commonly not adopted due to insufficient financing.
Exclusion of potentially damaging pathogens is the first line of defence against diseases. This can be achieved through controlling the movement of plants, propagation material, pathogens or vectors from geographical areas in which they occur. Furthermore, to reduce the risk of disease development in plantations, planting of disease resistant tree species should be a core objective in plantation establishment. Thus, government and private forestry companies should collaborate to form a strong and sustained tree breeding and selection programme that should focus on breeding resistant species of all economic trees.

It is essential for government and private forestry companies in the country to invest significantly in programmes and activities aimed at understanding the biology of pests and diseases. Such knowledge has a direct impact on silvicultural practices, breeding programmes and quarantine measures. In order to detect disease outbreaks, there should be regular plantation health surveys to monitor the incidence and severity of long standing diseases. Survey data collected consistently over many years may provide a sound basis for diagnosis and management of diseases.

Although diseases of Eucalyptus and Pinus have been well studied elsewhere, this review reveals the fact that the importance of pathogens in Zambian forestry plantations is poorly documented. It is evident from the literature presented that the incidence and severity of plantation diseases is likely to increase in future. Thus, the establishment of management strategies, with particular attention paid to silvicultural practices and planting of resistant trees in plantations can significantly reduce the impact of plantation diseases.

More comprehensive and accurate identification of the pathogens is required to provide the basis for sound disease management and quarantine procedures. Future studies should focus on using modern molecular and morphological techniques to enhance the understanding of the biology and genetics of pathogens associated with diseases of plantation forest trees in the country. Such knowledge will have a direct impact on silvicultural practices, breeding programmes and quarantine measures. In order to minimize risks associated with diseases of non-native trees in plantations, it is essential to have adequate information regarding the prevalence of disease causing organisms. This review highlights the need for studies on tree diseases in Zambia that will provide the necessary foundation to develop appropriate disease management strategies for the country.

\section{REFERENCES}

Barnes I., Crous P.W., Wingfield B.D., and Wingfield M.J., 2004. Multigene phylogenies reveal that red band needle blight of Pinus is caused by two distinct species of Dothistroma, D. septosporum and D. pini. Stud. Mycol. 50: 551-565.

Carniege A.J., Burgess T.I., Beilharz V., and Wingfield M.J., 2007. New species of Mycosphaerella from Myrtaceae in plantations and native forests in eastern Australia. Mycologia 99: 461-474.

Chidumayo E.N., 1989. Land use, deforestation and reforestation in the Zambian Copperbelt. Wiley Inter Science 1, pp. 209-216.

Chisanga E.C., Banda E.H., 2004. Necessities of Fire Protection in Zaffico Plantations, Monterey Printing and Packaging, Ndola, 76 p. 
Chungu D., Gryzenhout M., Muimba-Kankolongo A., Wingifield M.J., and Roux J., 2010. Taxonomy and pathogenicity of two novel Chrysoporthe species from Eucalyptus grandis and Syzygium guineense in Zambia. Mycol. Prog. (In Press). DOI:10.1007/s11557009-0646-9.

Coetzee M.P.A., Wingfield B.D., Bloomer P., and Wingfield M.J., 2005. Phylogenetic analyses of DNA sequences reveal species partitions amongst isolates of Armillaria from Africa. Mycol. Res. 109: $1223-1234$.

Cortinas M.N., Crous P.W., Wingfield B.D., and Wingfield M.J., 2006. Multi-gene phylogenies and phenotypic characters distinguish two species within the Colletogloeopsis zuluensis complex associated with Eucalyptus stem cankers. Stud. Mycol. 55: 133-146.

Coutinho T.A., Steenkamp E.T., Mongwaketsi K., Wilmot M., and Wingfield M.J., 2007. First outbreak of pitch canker in a South African pine plantation. Australas. Plant Pathol. 36: 265-261.

Crous P.W., Alfenas A.C., and Wingfield M.J., 1993. Calonectria scoparia and Calonectria morganii sp. nov., and variation among isolates of their Cylindrocladium anamorphs. Mycol. Res. 97: 701-708.

Crous P.W., Braun U., and Groenewald J.Z., 2007. Mycosphaerella is polyphyletic. Stud. Mycol. 58: 1-32.

Crous P.W., Wingfield M.J., Mansilla J.P., Alfenas A.C., and Groenewald J.Z., 2006. Phylogenetic reassessment of Mycosphaerella spp. and their anamorphs occurring on Eucalyptus II. Stud. Mycol. 55: 99-131.

CSIRO, 1996. Don't overfeed the trees! Ecos 87: 21-24. CSIRO, East Melbourne.

Durán A., Slippers B., Gryzenhout M., Ahumada R., Rotella A., Flores F., Wingfield B.D., and Wingfield M.J., 2008. Phytophthora pinifolia sp. nov. associated with a serious disease of Pinus radiata in Chile. Plant Pathol. 57: 715-727.

Evans J., 1992. Plantation Forestry in the Tropics, Oxford University Press, Oxford, $403 \mathrm{p}$.

FAO, 2007. The forest and tree resources of East and Southern Africa, in: State of forest genetic resources in Africa. www.fao.org.

Gibson I.A.S., 1975. Diseases of forest trees widely planted as exotics in the tropics and Southern Hemisphere. Part 1. Important members of the Myrtaceae, Leguminosae, and Meliace, Commonwealth Forestry Institute. University of Oxford, UK, pp. 21-34..

Gibson I.A.S., Christensen P.S., and Munga F.M., 1964. First observation of a foliage disease of pines in Kenya caused by Dothistroma pini Hulbary. Commonw. For. Rev. 43: 31-48.

Gryzenhout M., Wingfield B.D., and Wingfield M.J., 2009. Taxonomy, Phylogeny, and Ecology of Bark-infecting and tree killing Fungi in the Cryphonectriaceae. APS Press, Minnesota, USA.

Hunter G.C., Crous P.W., Carnegie A.J., and Wingfield M.J., 2009. Teratosphaeria nubilosa, a serious leaf disease pathogen of Eucalyptus spp. in native and introduced areas. Mol. Plant Pathol. 10: $1-14$.

Ivory M.H., 1994. Records of foliage pathogens of Pinus species in tropical countries. Plant Pathol. 43: 511-518.

Kile A.G. and Watling R., 1981. An expanded concept of Armillaria luteobubalina. Trans. Brit. Mycol. Soc. 81: 129-140.

Muimba-Kankolongo A., Nawa I.N., Roux J., and Ng'andwe P., 2009. Damage to foliage and stems caused by fungal pathogens in young eucalypt plantations in Zambia. Southern Forests 71: 171-178.

Mwenje E. and Ride J.P., 1996. Morphological and biochemical characteristics of Armillaria isolates from Zimbabwe. Plant Pathol. 45: 1036-1051.

Nakabonge G., Roux J., Gryzenhout M., and Wingfield M.J., 2006. Distribution of Cryphonectria canker pathogens on Eucalyptus and Syzygium spp. in Eastern and Southern Africa. Plant Dis. 90: 734-740.
Purnell R.C. and Lundquist J.E., 1987. Effects of Mycosphaerella leaf spot on growth of Eucalyptus nitens. Plant Dis. 108: 672-681.

Roberds J.H., Namkoong G., and Skrøppa T., 1990. Genetic analysis of risk in clonal populations of forest trees. Theor. Appl. Genet. 79: 841-848.

Roux J. and Apetorgbor M., 2009. First report of Chrysoporthe cubensis from Eucalyptus in Ghana. New Disease Reports Vol. 20, Sept 2009 to Jan 2010. http://www.bspp.org.uk/publications/ new-disease-reports/ndr.php.

Roux J., Coutinho T.A., Wingfield M.J., Bouillett J.P., and Leigh P., 2000. Diseases of plantation Eucalyptus in the Republic of Congo. S. Afr. J. Sci. 96: 454-456.

Roux J., Meke G., Kanyi B., Mbaga A., Hunter G.C., Nakabonge G., Heath R.N., and Wingfield M.J., 2005. Diseases of plantation forestry trees in eastern and southern Africa. S. Afr. J. Sci. 101: 1-5.

Roux J., Mthalane Z.L., de Beer Z.W., Eisenberg B., and Wingfield M.J., 2006. Quambalaria leaf and shoot blight on Eucalyptus nitens in South Africa Australas. Plant Pathol. 35: 427-433.

Shakacite O., 1991. A review of the pathology of Eucalyptus in Zambia. Research note No. 51, Division of Forest Research, Kitwe, Zambia.

Slippers B. and Wingfield M.J., 2007. Botryosphaeriaceae as endophytes and latent pathogens of woody plants: diversity, ecology and impact. Fungal Biology Review 21: 90-106.

Sichinga G., 2008. Sanitary problems and wood quality in residual Pinus kesiya trees associated with timber harvesting practices in ZAFFICO plantations. B.Sc. dissertation submitted in School of Natural Resources, Copperbelt University. Kitwe, Zambia.

Smith H., Wingfield M.J., Crous P.W., and Coutinho T.A., 1996. Sphaeropsis sapinea and Botryosphaeria dothidea endophytic in Pinus spp. and Eucalyptus spp. in South Africa. S. Afr. J. Bot. 62: $86-88$.

Van der Pas J.B., 1981. Reduced early growth rates of Pinus radiata caused by Dothistroma pini. New Zeal. J. For. Sci. 11: 210-220.

Van Heerden S.W. and Wingfield M.J., 2002. Effect of environment on the response of Eucalyptus clones to inoculation with Cryphonectria cubensis. For. Pathol. 32: 395-402.

Wall E. and Keane P.J., 1984. Leaf spot of Eucalyptus spp. caused by Aulographina eucalypti. Trans. Brit. Mycol. Soc. 82: 257-273.

Wingfield B.D., Maphosa L., Coetzee M.P.A., Mwenje E., and Wingfield M.J., 2009. Characterization of Zimbabwean Armillaria using IGS-1 sequences and AFLPs. Fungal Divers 34: 185-194.

Wingfield M.J., 1987. Foliar pathogens of Eucalyptus in South Africa. Phytophylactica 19: 123.

Wingfield M.J., Crous P.W., and Coutinho T.A., 1997. A serious canker disease of Eucalyptus in South Africa caused by a new species of Coniothyrium. Mycopathologia 136: 139-145.

Wingfield M.J. and Knox-Davies P.S., 1980. Association of Diplodia pinea with a root disease of pines in South Africa. Plant Dis. 64: 221-223.

Wingfield M.J., Slippers B., Hurley B.P., Coutinho T.A., Wingfield B.D., and Roux J., 2008. Eucalypt pests and diseases: growing threats to plantation productivity. Southern Forests 70: 139-144.

Wingfield M.J., Swart W.J., and Kemp G.H.J., 1991. Pathological considerations in clonal propagation of Eucalyptus with special reference to the South Africa situation. In: Proceedings of the IUFRO International Symposium on Intensive Forestry: The role of Eucalyptus, Durban 2-6 Sept., pp. 811-820.

Zwolinski J.B., Swart W.J., and Wingfield M.J., 1990. Intensity of dieback induced by Sphaeropsis sapinea in relation to site conditions. Eur. J. For. Pathol. 20: 167-174. 